\title{
The Impact of Audit Committee's Financial Expertise and Status on Accrual Earnings Management
}

\author{
Rindi Fitria Dewi ${ }^{1}$, Aria Farah Mita ${ }^{2 *}$ \\ 1,2Faculty of Economics and Business, Universitas Indonesia, \\ Jl. Salemba Raya, Depok 16424, Jakarta, Indonesia \\ *Corresponding author; Email: aria.farahmita@ui.ac.id
}

\begin{abstract}
This research aims to study the impact of the audit committee's financial expertise and status on accrual earnings management. This study focuses on the status of audit committee relatives to the board of director. Status is measured by their current or previous employment in the BEI listed companies, the intra-industry of BEI listed companies, the financial companies of BEI listed or in the financial institutions; in the government; and a degree from elite educational institutions. A sample of non-financial companies is used with a period observation of 2015-2016 and a total observation of 580 firm-years. The result of this research indicates that the audit committee financial expertise has a significant effect on accrual earnings management. The audit committee status has no significant effect on accrual earnings management.
\end{abstract}

Keywords: Earnings management; financial expertise; status; audit committee.

\section{INTRODUCTION}

Earning management is a management's opportunistic act that alters income and profits in order to cover up the actual financial condition. [14]. There were several cases of earnings management, such as Enron (2001) and WorldCom (2002). In Indonesia, there were also the cases of Kimia Farma (2002) and Great River Garment (2003). All cases of earning management are basically altering the financial report to look more profitable, even though the real condition is different, which even causes several companies to go bankrupt. This act of earning management that inflicts financial losses to the companies and stakeholders has to be prevented, one of the preventive moves is through good supervision of the company's management. The supervision could be done externally by external auditors and internally by the board of commissioners and audit committee. Facing the act of earning management, in Indonesia, audit committee who supports the board of commissionners in supervising the company's financial information, according to Financial Services Authority's Regulation No.55/POJK.04/2015 about and the Formation and Guidelines of Audit Committee Works, is required to have at least 1 member who has an educational background and expertise in finance and accounting

[6] and [16] indicate that an audit committee with financial expertise could improve corporate internal control. [24] shows that financial expertise improves company's performance because it improves the quality of the company's financial report and lowers the cost of debt, and makes it easier for the company to get funding. [9] and [22] say that market participants give positive responses to the existence of an audit committee with financial expertise. Many studies have proven that the financial expertise of an audit committee can improve his/her effectivity in suppressing the possibility of earnings management through abnormal accruals, as can be seen in the research of [1], [2], [5], and [10].

The relationship between the audit committee and the company's management could cause a conflict [23], such as conflict of interests or agency problem between the principal (stakeholders) and agent (management). Management tends to misreport so that the financial statements will be in line with their interest, while committee audit tends to suppress the opportunistic behaviour of the managements because there are consequences to their career if there are problems with the financial report [23]. In other words, conflict happens because the managements have the tendency to behave opportunistically by altering the financial report to do accrual earnings management.

The financial expertise of an audit committee is meant to give the audit committee with sufficient knowledge for their task of supervising financial reports so that he/she cannot be manipulated by the management. Financial expertise still cannot guarantee that earning managements 
will be prevented thoroughly, and is also not enough to solve the conflicts. Besides financial expertise, an audit committee also has to have more influence than the management so that the management will be more appreciative, respectful, and willing to obey the audit committee [7] and [19]. The management will also consider the audit committee to be more competent and will directly drop their opportunistic acts and feel compelled to present the financial report as it is.

Audit committee's power of influence comes from their status and prestige. The status of the audit committee is associated with their ability to influence others through their expertise and quality [7] and [19], while prestige shows their competency, credibility, and reliability [7]. Several studies have found that the status of the leader can influence the company's outcomes, especially in activities that involved uncertainty. However because there is no ideal empiric measurement for status [13], these following studies have developed the characteristics of the measurement.

[7] found that the management who has high relative status and prestige from being a member of the political elite (government and financial company) and board connection could reduce the risk of bankruptcy. [19] found that the status of management before the Initial Public Offering (IPO) has a positive relation to the IPO valuation, the status is measured by the work experience in prestigious companies, blue-chip corporation, and a degree from elite educational institutions. [11] found that the audit committee with financial expertise has a lower relative status than other board members, according to [4] the status is measured from the number of a similar position, trusteeship, member of social society, and elite education. So people who have a connection with government or financial/company, career experience in prestigious companies, and a degree from elite educational institutions.

The previous research about the relations between financial expertise and the status of audit committee towards earnings management was done by [3] in the USA. This research made a comparison between the audit committee's status and management's status to measure earnings management via abnormal accrual. Status is measured from public board indicator, private boards, and elite education. The result shows that interaction between financial expertise and the status of the audit committee has an influence on the low number of abnormal accruals.

Status and prestige are needed to limit earnings management, but [3] shows a different result than [21].

[21] shows that higher status of audit committee's members than the management's (CEO and
CFO) have no significant impact on financial expertise in mitigating accrual earnings management. Status in the research done by [21] is measured with the following indicators: graduating from an elite university, educational degree, and multiple leadership.

The purpose of this study is to examine the relations between financial expertise and status of the audit committee to the act of accrual earnings management. The samples of this study are nonfinance companies registered in BEI in 2015 and 2016. This study is done by making a comparison between the audit committee's status and management's based on [3] and [4]. Different with [3] and [21], status is measured by their current or previous employment in the BEI listed companies [4], [11], [12], [19], and [21]; the intra-industry of BEI listed companies [19]; the financial companies of BEI listed or in the financial institutions [7]; in the government [7], [4], [11], and [12]; and a degree from elite educational institutions [3], [4], [11], [12], [19], and [21]. Other than that, status in this research is used as an independent variable, not as a moderator variable like in [3] and [21]. The list of elite educational institutions is based on the List of Universities from Indonesia Endowment Fund for Education (LPDP) Scholarship in 2017 because the prestige of the educational institution has already measured. Status's characteristics in [3], such as public board indicator, and private boards, is not used because of the lack of the source data available. [13] also stated that the measurement of status in [3] is complex because there is no standardization, unlike [4], [11], [12], [19], and [21].

\section{Hypothesis Development}

\section{Effect of Financial Expertise of Audit Com- mittee on Accrual Earnings Management}

Accrual earnings management is done by altering accrual components in the financial report because they are easy to manipulate so they can be used to manage the company's finance. According to POJK No.55/POJK.04.2015 about the Formation and Guidelines of Audit Committee Works, an audit committee that helped the board of commissioners in monitoring financial report of the company needs to have a member with financial expertise. The member of the audit committee with financial expertise could improve the internal control of the company [6] and [16], improve the quality of company's financial report [24], and improve positive responses from market participants [9] and [22]. Some studies [1], [2], [5], and [10] have proven the financial expertise of audit committee can improve the effectiveness of earnings management (abnormal accruals) mitigation. 
Financial expertise gives the audit committee appropriate knowledge to monitoring finance of the company and in understanding financial report. Audit committee with more member with financial expertise in it would have a better performance in monitoring financial report of the company. So, the first hypothesis of this study is:

H1: Financial expertise of audit committee gives a negative impact on the act of accrual earnings management.

\section{Effect of Status of Audit Committee on Accrual Earnings Management}

The relation between audit committee (supervisor) and the company's management (supervised) could cause a conflict [23], like a conflict of interest or agency problem between stakeholders and management. Management tends to misreport so that the financial statements will be in line with their interest, while committee audit tends to suppress the opportunistic behaviour of the managements because there are consequences to their career if there are problems with the financial report [23]. In other words, conflict happens because the managements have the tendency to behave opportunistically by altering the financial report to do accrual earnings management.

The financial expertise of an audit committee is meant to give the audit committee with sufficient knowledge for their task of supervising financial reports so that he/she cannot be manipulated by the management. Financial expertise still cannot guarantee that earning managements will be prevented thoroughly, and is also not enough to solve the conflicts. Besides financial expertise, an audit committee also has to have more influence than the management so that the management will be more appreciative, respectful, and willing to obey the audit committee [7] and [19]. The management will also consider the audit committee to be more competent and will directly drop their opportunistic acts and feel compelled to present the financial report as it is.

Audit committee's power of influence comes from their status and prestige. The status of the audit committee is associated with their ability to influence others through their expertise and quality [7] and [19], while prestige shows their competency, credibility, and reliability [7].

Status is measured by their current or previous employment in the BEI listed companies, the intra-industry of BEI listed companies, the financial companies of BEI listed or in the financial institutions, in the government, and a degree from elite educational institutions. So, the second hypothesis of this study is:
H2: The status of the audit committee has a negative impact on accrual earnings management.

\section{RESEARCH METHOD}

Hypothesis validation is modeled with this regression equation:

$$
\begin{gathered}
D A C C_{i t}=\beta_{0}+\beta_{1} E X P_{i t}+\beta_{2} S_{T A T D I F}+\beta_{3} \text { SIZE }_{i t} \\
+\beta_{4} L E V_{i t}+\beta_{5} R_{i t}+\beta_{6} G R O W_{i t}+\beta_{7} C F O_{i t}+ \\
\beta_{8} L O S S_{i t}+e_{i t}
\end{gathered}
$$

Notes:

DACC $_{\text {it }} \quad$ : Accrual discretionary of the $i$ company on the $t$ period;

EXPit $_{\text {it }}$ : Percentage of the audit committee with financial expertise in the $i$ company on the $t$ period;

STATDIF it: Comparison of audit committee's status index and board of directors' status index on the $i$ company on the $t$ period (the dummy variable, the score is 1 if audit committee's status index is higher than the board of directors', 0 , if else);

SIZE $_{\text {it }}$ : Natural logarithm value of the total asset of the $i$ company on the $t$ period;

$\mathrm{LEV}_{\text {it }} \quad$ : Ratio of total debt to the total asset of the $i$ company on the $t$ period;

$R O A_{i} \quad$ : Return on assets of the $i$ company on the $t$ period;

GROWit : Growth of company asset of the $i$ company on the $t$ period;

$\mathrm{CFO}_{\text {it }}$ : Operational cash flow at the beginning of the year of the $i$ company on the $t$ period;

LOSS $_{\mathrm{it}} \quad$ : Dummy variable of loss of the $i$ company on the $t$ period;

eit : error.

\section{Dependent Variable}

Accrual earnings variable as a dependent variable is measured by discretionary accrual approach that developed by [16].

\section{Independent Variable}

\section{Financial Expertise}

Financial expertise of the audit committee is measured by the percentage of audit committee's members with finance or accounting educational background. This variable is expected to have a negative value.

\section{Status}

Status of the audit committee and the status of management will be measured and compared who has a higher relative status (STATDIF). The comparison is done like other studies [3], [4], and 
[11]. The status is measured from 5 characteristics that adopted from other studies [21], [4], [11], [12], and [19], that is .by their current or previous employment in the BEI listed companies, the intraindustry of BEI listed companies, the financial companies of BEI listed or in the financial institutions, in the government, and a degree from elite educational institutions. The steps of status measurement can be seen in the Appendix. This variable is expected to have a negative value.

\section{Control variable}

1. Company size (SIZE), expected to have positive and negative value [10] and [22].

2. Leverage (LEV), expected to have positive value [3].

3. Return on Asset (ROA), expected to have positive value [3].

4. Company's growth rate (GROW), expected to have positive value [8].

5. Operating cash flow (CFO), expected to have a negative value [5].

6. Losses (LOSS), expected to have positive value [10].

\section{Sample and Population}

The Data of this study is gathered from BEI website (www.idx.co.id) and Thomson Reuters Eikon. Sample criteria used in this study are: (1) listed on BEI during research period, (2) nonfinance corporations, (3) have annual report and financial report that ended on December $31^{\text {st }}$, 2015 and December 31'st, 2016, (4) Uses Rupiah (IDR) as the currency in financial report. The summary of sample criteria used in this study can be seen in Table 1.

Table 1. Summary of the sample criteria

\begin{tabular}{lc}
\hline \multicolumn{2}{c}{ Jumlah } \\
\hline Number of companies listed on BEI in 2015 and \\
2016 & 558 \\
Number of finance company listed on BEI in & \\
2015 and 2016 & $(96)$ \\
Number of companies that did not use rupiah as & \\
currency in their financial report & $(53)$ \\
Number of companies with insufficient informa- & \\
tion & $(106)$ \\
Outlier & $(13)$ \\
Number of sample companies & 290 \\
Number of observed years & x2 \\
\hline Total number of sample & 580 \\
\hline
\end{tabular}

\section{RESULTS AND DISCUSSION}

\section{Descriptive Statistics Analysis}

All of the descriptive statistics done in this study is presented in Table 2. Data presented in Table 2 are data after winsorizing. Winsorizing is done to $0,8 \%$ DACC variable (5 out of 580 ), $0,3 \%$ LEV variable (2 out of 580 ), $0,3 \%$ ROA variable (3 out of 580 ), $0,8 \%$ GROW variable (5 out of 580 ), and $0,6 \%$ CFO variable (4 out of 580 ).

The value of the standard deviation in Table 2 is 0,06555 . That value indicated the variation of the data is not large. DACC value has a big range, from 0,00009 to 0,45358 . The lowest value of EXP variable is 0,2 . That value indicated that all sample companies are obeyed POJK No.55/POJK.04. 2015 about the Formation and Guidelines of Audit Committee Works that a company has to have a minimal 1 audit committee's member with financial expertise. $68,1 \%$ (395 out of 580) sample companies have more than 1 audit committee's member with financial expertise. That shows the companies realize the importance of financial expertise in internal monitoring effectiveness.

The dummy variable STATDIF shows that $41,03 \%$ sample (238 out of 580) have an audit committee with higher relative status than the management. This value corresponds to the result of the study on [11], which stated that the number of companies whose audit committee has lower relative status than the other boards is higher than the opposite. Only a few members of audit committee in these sample data fit into status criteria, $81,15 \%$ are currently or previously working for the BEI listed companies, $8,97 \%$ in the similar industries as the BEI listed companies, $20,52 \%$ in the financial companies listed in BEI or in the financial institutions, $14,75 \%$ work for the government, and $42,73 \%$ have elite educational degree.

Member of board of directors that fit into sample criteria also few in number, there are $94,36 \%$ are currently or previously working in the BEI listed companies, 9,55\% work in the similar industries as the BEI listed companies, 9,83\% in the financial companies listed in BEI or in the financial institutions, 2,06\% work for the government, and 56,40\% have elite educational degree. The members of the audit committee only have a higher relative status than a member of the board of directors on 2 criteria, that is currently or previously working in the BEI listed companies and in the government.

The result of the Pearson correlation test on Table 3 shows that EXP and STATDIF did not have a significant impact on DACC, but EXP and STATDIF have a negative significant impact when $a=1 \%$, which shows that the higher the percenttage of the audit committee with financial expertise, the lower the status. SIZE and CFO also have a negative significant impact on DACC. Meanwhile, LEV, GROW, and LOSS has a positive significant impact on DACC. 
Table 2. Descriptive Statistics

\begin{tabular}{lcrrrr}
\hline \multicolumn{1}{c}{ Variable } & N & Mean & St. Dev & Min & Max \\
\hline DACC & 580 & 0,06752 & 0,06555 & 0,00009 & 0,45358 \\
EXP & 580 & 0,63005 & 0,24560 & 0,2 & 1 \\
SIZE (in Billion Rp) & 580 & 9.435 & 21.712 & 46.760 & 261.855 \\
LEV & 580 & 0,24212 & 0,18844 & 0 & 0,86455 \\
ROA & 580 & 0,03843 & 0,09059 & $-0,24877$ & 0,45788 \\
GROW & 580 & 0,09775 & 0,16565 & $-0,43744$ & 0,80272 \\
CFO & 580 & 0,06676 & 0,11021 & $-0,29459$ & 0,65896 \\
& & Score 1 & Score 0 & & \\
STATDIF & 580 & $41,03 \%$ & $58,96 \%$ & & \\
LOSS & 580 & $24,65 \%$ & $75,34 \%$ & & \\
\hline
\end{tabular}

Table 3. Pearson Correlation Test

\begin{tabular}{|c|c|c|c|c|c|c|c|c|c|}
\hline & DACC & EXP & STATDIF & SIZE & LEV & ROA & GROW & CFO & LOSS \\
\hline $\mathrm{DACC}$ & 1.0000 & & & & & & & & \\
\hline EXP & $\begin{array}{l}-0.0294 \\
(0.4792)\end{array}$ & 1.0000 & & & & & & & \\
\hline STATDI & -0.0002 & $-0.1484^{* * * *}$ & 1.0000 & & & & & & \\
\hline $\mathrm{F}$ & (0.9953) & $(0.0003)$ & & & & & & & \\
\hline SIZE & $\begin{array}{l}-0.1422^{* * * *} \\
(0.0006)\end{array}$ & $\begin{array}{l}-0.0624 \\
(0.1333)\end{array}$ & $\begin{array}{l}0.1511^{* * * *} \\
(0.0003)\end{array}$ & 1.0000 & & & & & \\
\hline LEV & $\begin{array}{l}0.1032^{* * * *} \\
(0.0129)\end{array}$ & $\begin{array}{l}0.0405 \\
(0.3302)\end{array}$ & $\begin{array}{l}-0.1303^{* * *} \\
(0.0017)\end{array}$ & $\begin{array}{l}0.2357^{* * * *} \\
(0.0000)\end{array}$ & 1.0000 & & & & \\
\hline $\mathrm{ROA}$ & $\begin{array}{l}0.0173 \\
(0.6767)\end{array}$ & $\begin{array}{l}-0.0211 \\
(0.6119)\end{array}$ & $\begin{array}{l}0.1202^{* * * *} \\
(0.0037)\end{array}$ & $\begin{array}{l}0.1120^{* * * *} \\
(0.0069)\end{array}$ & $\begin{array}{l}-0.2852^{* * * *} \\
(0.0000)\end{array}$ & 1.0000 & & & \\
\hline GROW & $\begin{array}{l}-0.0961^{* *} \\
(0.0207)\end{array}$ & $\begin{array}{l}0.0174 \\
(0.6756)\end{array}$ & $\begin{array}{l}0.0585 \\
(0.1595)\end{array}$ & $\begin{array}{l}0.0741^{*} \\
(0.0746)\end{array}$ & $\begin{array}{l}-0.0447 \\
(0.2829)\end{array}$ & $\begin{array}{l}0.2522^{* * *} \\
(0.0000)\end{array}$ & 1.0000 & & \\
\hline $\mathrm{CFO}$ & $\begin{array}{l}-0,1160^{* * * *} \\
(0,0051)\end{array}$ & $\begin{array}{l}0,0262 \\
(0,5284)\end{array}$ & $\begin{array}{l}0,0774 * \\
(0,0624)\end{array}$ & $\begin{array}{l}0,0868 * * \\
(0,0367)\end{array}$ & $\begin{array}{l}-0,1969 * * * \\
(0,0000)\end{array}$ & $\begin{array}{l}0,5508^{* * *} \\
(0,0000)\end{array}$ & $\begin{array}{l}-0,0052 \\
(0,9013)\end{array}$ & 1.0000 & \\
\hline LOSS & $\begin{array}{l}0,0921^{* *} \\
(0,0265)\end{array}$ & $\begin{array}{l}0,0367 \\
(0,3775)\end{array}$ & $\begin{array}{l}-0,1194^{* * *} \\
(0,0040)\end{array}$ & $\begin{array}{l}-0,1405^{* * * *} \\
(0,0007)\end{array}$ & $\begin{array}{l}0,2031^{* * * *} \\
(0,0000)\end{array}$ & $\begin{array}{l}-0,6308^{* * *} \\
(0,0000)\end{array}$ & $\begin{array}{l}-0,2494^{* * * *} \\
(0,0000)\end{array}$ & $\begin{array}{l}0,2694^{* * * *} \\
(0,0000)\end{array}$ & 1.0000 \\
\hline
\end{tabular}

Notes: * significant when $\alpha=10 \%$; ${ }^{* *}$ significant when $\alpha=5 \%$; ${ }^{* * *}$ significant when $\alpha=1 \%$.

\section{Regression Analysis}

Regression is done by the most appropriate panel model, which is the Fixed Effect model (FE). The result of the classic assumption test shows that there is multicollinearity on SIZE variable and heteroscedasticity. Multicollinearity and heteroscedasticity are solved using centring treatment and Generalized Least Squares (GLS) so the data are BLUE (Best Linear Unbiased Estimator). The results are shown in Table 4.

Table 4. Results of Model Validation

\begin{tabular}{|c|c|c|}
\hline Variable & $\begin{array}{c}\text { Sign } \\
\text { Prediction } \\
\end{array}$ & Coefficient Prob t-stat \\
\hline$\overline{\mathrm{EXP}}$ & $(-)$ & $-0.01380 .097^{*}$ \\
\hline STATDIF & $(-)$ & 0.00510 .173 \\
\hline SIZE & $(+/-)$ & $-0.00780 .000^{* * * *}$ \\
\hline LEV & $(+)$ & $0.05730 .000^{* * * *}$ \\
\hline ROA & $(+)$ & $0.19580 .000^{* * * *}$ \\
\hline GROW & $(+)$ & $0.04040 .006^{* * * *}$ \\
\hline $\mathrm{CFO}$ & $(-)$ & $-0.09820 .000^{* * *}$ \\
\hline LOSS & $(+)$ & $0.02890 .000^{* * * *}$ \\
\hline $\mathrm{R}$ sq (within) & 0.0853 & \\
\hline Prob F-stat & 0.0000 & \\
\hline $\mathrm{N}$ & 580 & \\
\hline
\end{tabular}

Effect of Financial Expertise of Audit Committee on Earnings Management

Hypothesis 1 validation is done to find out the negative effect of financial expertise of audit committee on accrual earnings management. Prob-t statistic and coefficient of independent variable EXP are 0,097 and -0,0138 respectively. The results show that EXP variable has a negative significant impact on DACC (when $\alpha=10 \%$ ) so financial expertise of audit committee have a negative impact on accrual earnings management on $90 \%$ level of confidence. A higher percentage of the member with financial expertise in audit committee would results in a lower accrual earnings management that done by the company. From this result, H1 is accepted and match with the result of studies [1]. [2], [3], and [5], that financial expertise of audit committee can reduce accrual earnings management that done by the company.

This result also proves that member of the audit committee with financial expertise gives sufficient knowledge regarding finance to the audit committee, so the audit committee is becoming more competent in controlling and monitoring financial report of the management. 
Financial expertise gives knowledge to the audit committee to rival the management's financial expertise. Management tends to use accounting's loopholes to fulfil their interests as they handle the company's operation. Financial expertise of audit committee can reduce adverse selection that could make agency problem, so the role of the audit committee as an internal monitoring mechanism could be effective.

\section{Effect of Status of Audit Committee on Earnings Management}

Hypothesis 2 validation is done to find out the negative effect of status of the audit committee on accrual earnings management. Prob t-statistic and coefficient of independent variable STATDIF on Table 3 are 0,173 and 0,0051 respectively. The results show that STATDIF variable does not have a significant impact on the DACC variable, so a higher or lower relative status of audit committee does not affect accrual earnings management done by the company. From these results, H2 is rejected.

This results don't reflect the result of study [3] that stated a higher relative status of audit committee could reduce management's earnings management activity, but this results conform with the result of study [21] that stated that the relative status of audit committee that is higher than the boards does not strengthen the negative influence of financial expertise on accrual earnings management.

There is also a possibility that $\mathrm{H} 2$ is rejected because the observation period is only 2 years, 2015 and 2016. Because of this, the rate of the audit committee and board of directors change tends to be lower, this is in accordance to the limit of employment period in POJK No.33/POJK.04/ 2014 about the Directorate and Board of Commissionaires of Issuers or Public and POJK No.55/ POJK.04.2015 about the Formation and Guidelines of Audit Committee Works. Thus, the sample cannot represent the influence of higher relative status of the audit committee, that caused the management to be more respectful to the audit committee and reduce accrual earnings management. The sample used in the study [3] has a longer observation period, which is 8 years.

\section{Effect of Control Variable on Earnings Quality}

All of the control variables in this study show a significant effect on dependent variable DACC when $\alpha=1 \%$. Size variable shows a negative significant impact on DACC variable and matches with the result of other studies [5], [16], and [22].
This result shows that the bigger company would make an internal monitoring mechanism to be better to keep their good reputation so they reduce their accrual earnings management. LEV shows a positive significant impact on DACC variable. This result shows that the company tends to do accrual earnings management to invite the investor as the company's debt increasing and match with the result of other studies [3] and [5]. ROA variable shows a positive significant impact on variable DACC. ROA becomes a driving force of accrual earnings management because there is an incentive received by the management.

GROW variable shows a positive significant impact on DACC variable. This result matches the result of other studies [22] that stated the bigger growth of the company indicates a rising accrual earnings management done by the company to invite the investor. CFO variable shows a negative significant impact on DACC variable. This result matches the result of other studies [5] and [8] that stated the bigger operational cash flow reduces accrual earnings management done by the company. LOSS variable shows a positive significant impact on variable DACC. This result matches the result of other studies [10] and [16] that stated the bigger company's financial loss increases accrual earnings management in order to invite investors.

\section{CONCLUSION}

Based on previous analysis, the conclusion of this study is: (1) Financial expertise of the audit committee have a negative significant impact on accrual earnings management. Audit committee with financial expertise would have sufficient knowledge about the financial state of the company, so the financial report monitoring could be tightened and reduces accrual earnings management done by the company. The more audit committee with financial expertise, the fewer accrual earnings management done by the company. (2) The higher relative status of audit committee didn't have a significant impact on accrual earnings management done by the company. It might be caused by the status measurement for both the audit committee and management didn't represent the actual value of the status.

This study gives implication to regulators, stakeholders, and investors. The regulator should consider other competency factors of audit committee aside from having minimal 1 member with financial expertise. Stakeholders and investors should pay attention to the qualification of the audit committee and management including career experience and educational background because competency factor and qualification of 
audit committee determine the audit committee's effectiveness in monitoring the management. So stakeholders and investors could choose the right person to represent their position on the board of commissioners, the board of directors, and the audit committee.

The limitations of this study are on the comparison of the audit committee's status score and the management's that based on the average status score in a company in a year. It might not represent the actual status. For future research, the method of comparing the status should be represented the actual status, increasing criteria of status measurement, increasing the sample, and considering real earnings management as a dependent variable.

\section{REFERENCES}

[1] Abdillah, Musavie. (2011). Pengaruh Efektifitas Dewan Komisaris dan Komite Audit terhadap Manajemen Laba. Tesis Program Magister Akuntansi Fakultas Ekonomi. Universitas Indonesia.

[2] Argantoro, Robertus Dhelon Widaru. (2014). Analisis Pengaruh Kualitas Audit, Efektivitas Dewan Komisaris, dan Efektivitas Komite Audit Terhadap Manajemen Laba pada Emiten Manufaktur. Tesis Progam Magister Akuntansi Fakultas Ekonomi. Universitas Indonesia.

[3] Badolato, P. G., Donelson, D. C., and Ege, M. (2014). Audit committee financial expertise and earnings management: The role of status. Journal of Accounting and Economics, 58, 208-230.

[4] Belliveau, M.A., O'Reilly, C.A., dan Wade, J.B. (1996). Social Capital at the Top: Effect of Social Similarity and Status on CEO Compensation. The Academy of Management Journal, 39(6), 1568-1593.

[5] Carcello, J.V., Hollingsworth, C.W., Klien, April., and Neal, T. L. (2006). Audit committee financial expertise, competing corporate governance mechanisms, and earnings management. NYU Stern School of Business Research Paper Series.

[6] Cohen, J.R., Hayes, C., Krishnamoorthy, G., Monroe, G.S., and Wright, A.M. (2013) The effectiveness of SOX regulation: an interview study of corporate directors. Behavioral Research in Accounting, 25(1), 61-87.

[7] D’Aveni, R. (1990). Top managerial status and organizational bankruptcy. Organizational Science 1, 121-142.

[8] Davidson, W. N. , Xie, B., Xu, W. (2004). Market reaction to voluntary announcements of audit committee appointments: the effect of financial expertise. Journal of Accounting and Public Policy, 23, 279-293.

[9] Dechow and I. D., Dichev. (2002). The quality of accruals and earnings: The role of accrual estimation errors. The Accounting Review, 77, 35-59.

[10] DeFond, M., Hann,R., and Hu, X. (2005). Does the market value financial expertise on audit committees of boards of directors? Journal of Accounting Research, 43, 153-193.

[11] Dhaliwal, D., Naiker, V., and Navissi, F. (2010). The association between accruals quality and the characteristics of accounting experts and mix of expertise on audit committees. Contemporary Accounting Research, 27(3), 787-827.

[12] Erkens, D.H., Bonner,S.E. (2013). The role of firm status in appointments of accounting financial experts to audit committees. The Accounting Review, 88(1).

[13] Finkelstein, Sydney. (1992). Power in Top Management Teams: Dimensions, Measurement, and Validation. The Academy of Management, 35(3), 505-538.

[14] Hayes, Rachel M. (2014). Discussing of "Audit committee financial expertise and earnings management: The role of status" by Badolato, Donelson, and Ege (2014). Journal of Accounting and Economics, 58, 231-239.

[15] Healy, P. and J. Wahlen. (1999). A review of the earnings management literature and its implications for standard setting. Accounting Horizons,13(4), 365-383.

[16] Jensen, M.C. and W.H. Meckling. (1976). Theory of the firm: Managerial behavior, agency costs and ownership structure. Journal of Financial Economics, 3(4), 305-360.

[17] Krishnan, Jayanthi. (2005). Audit Committee Quality and Internal Control: An Empirical Analysis. The Accounting Review, 80(2), 649675.

[18] Lembaga Pengelola Dana Pendidikan Kementrian Keuangan Republik Indonesia. (Februari, 2017). Daftar Perguruan Tinggi Tujuam LPDP Tahun 2017. Diunduh 11 Oktober 2017, dari http://www.lpdp.kemenkeu.go.id/wpcontent/uploads/2017/02/Daftar-PerguruanTinggi-Tujuan-LPDP-tahun-2017.pdf

[19] Peraturan Otoritas Jasa Keuangan No. 55/POJK.04/2015 tentang Pembentukan dan Pedoman Pelaksanaan Kerja Komite Audit

[20] Pollock, T., Chen, G., Jackson, E., Hambrick, D. (2010). How much prestige is enough? Assessing the value of multipletypes of highstatus affiliates for young firms. Journal of Business Venturing, 25, 6-23. 
[21] Scott, W. R., Financial Accounting Theory, Sixth Edition, PrenticeHall International, USA, 2012.

[22] Siagian, Delfita. (2015). Pengaruh Keuahlian Keuangan Anggota Komite Audit terhadap Manajemen Laba dengan Peran Status sebagai Variabel Moderasi. Skripsi Progam Sarjana Akuntansi Fakultas Ekonomi. Universitas Indonesia.

[23] Singhvi, M., Rama, D.V., and Barua, A. (2013). Market reactions to departures of audit committee directors. Accounting Horizons, 27(1), 113-128.

[24] Srinivasan, S. (2005). Consequences of financial reporting failure for outside directors: evidence from accounting restatements and audit committee members. Journal of Accounting Research, 43, 291-334.

[25] Wulandari, Septiana. (2016). Pengaruh Karakteristik Komite Audit terhadap Kinerja Perusahaan pada Perusahaan Non-Financial. Skripsi Progam Studi Sarjana Akuntansi Fakultas Ekonomi. Universitas Indonesia.

\section{APPENDIX}

Here are the steps in STATDIF calculation:

1. Calculate the total score of the status of each member of the audit committee and board of directors in each company on a year, the characteristics that used in calculations are:

1) Previously or currently have employment in the BEI listed companies

The score is 1 if they previously or currently have employment in BEI listed companies, 0 if-else. The scoring is done like other studies [3], [11], and [4].

2) Previously or currently have employment in the intra-industry of BEI listed companies The score is 1 if they previously or currently have employment in the intra-industry of BEI listed companies, 0 if-else. The scoring is done like other studies [3], [11], and [4].

3) Previously or currently have employment in the financial companies of BEI listed or in the financial institutions

Financial companies are including bank financial institutions and non-bank financial institutions, which include leasing companies, insurance companies, pension funds institutions, mutual funds companies, guarantor companies, venture capital firms, and pawnbrokers. The score is 1 if they pre- viously or currently have employment in the financial companies of BEI listed or in the financial institutions, 0 if-else. The scoring is done like other studies [3], [4], and [11].

4) Previously or currently have employment in the government

The score is 1 if they previously or currently have employment in the government, 0 ifelse. The scoring is done like other studies [3], [4], and [11].

5) A degree from elite educational institutions The list of elite educational institutions is based on the List of Universities from Indonesia Endowment Fund for Education (LPDP) Scholarship in 2017. The scoring is done like in other studies [4] and [11], that is:

- 2 , if the bachelor, master, or doctoral degree comes from the institution listed on LPDP's List of Foreign Universities

- 1 , if the bachelor, master, or doctoral degree comes from the institution listed on LPDP's List of Domestic Universities

- 0 , if-else.

2. Calculate the average score of status from each member of the audit committee and board of directors in each company on a year (Total score from Step 1). Then, the average score is standardized for all companies in a year. Standardization is done to get the index of status that could represent the actual score of the status of the audit committee and board of directors in the sample and be compared to each other.

3. Calculate the average score and deviation standard of score from all audit committee and board of directors of all companies on a year (Score from Step 2).

4. Calculate each index of status of the audit committee and board of directors in each company on a year, with subtracting the average score of status from each member of the audit committee and board of directors in each company on a year (Score from Step 2) with the average score of all audit committee and board of directors on a year (Score from Step 3). Then divided with deviation standard of the score of all audit committee and board of directors on a year (Deviation standard from Step 3).

5. Compare the index of the status of the audit committee and board of directors to create a dummy variable. The value of the variable is 1 if the audit committee's status index is higher than the board of directors' status index, 0 ifelse. 